\title{
A Comparative Study on the Effects of Coconut Water Based Extenders on the Quality of Kintamani Dog Semen Preserved at $4^{\circ} \mathrm{C}$
}

\section{Ketut Puja ${ }^{1}$, Ni Made Sawitri ${ }^{1}$, Nisa Maharani ${ }^{1}$, I Wayan Nico Fajar Gunawan ${ }^{2}$, Luh Gde SRI Surya Heryani ${ }^{3}$}

\begin{abstract}
${ }^{1}$ Veterinary Genetics and Reproduction Technology Laboratory, Faculty of Veterinary Medicine, Udayana University, Bali, Indonesia; ${ }^{2}$ Veterinary Surgery and Radiology Laboratory, Faculty of Veterinary Medicine, Udayana University, Bali, Indonesia; ${ }^{3}$ Laboratory of Veterinary Anatomy, Faculty of Veterinary Medicine, Udayana University, Bali, Indonesia.
\end{abstract}

\begin{abstract}
The objective of this study was to determined the effects of different extenders on chilled kintamani dog semen quality parameters. In this study, the impact of extenders on motility, viability and DNA integrity of kintamani dog semen were investigated. A total of 12 -second fraction of ejaculates were collected from four kintamani dogs using manual stimulation. Sperms were diluted in each of the five extenders at room temperature and then cooled to $4^{0} \mathrm{C}$. Samples were then evaluated every day until five days. Chilled semen samples were assessed for motility, viability and DNA integrity. Results showed that the progressive motility of the sperm cells was significantly higher in extender A and B compared to other extenders. The extender containing $20 \%$ egg yolk and $20 \%$ tender coconut water preserved the motility of more than $60 \%$ of the spermatozoa up to the day 5 post-sampling. Percentage of live sperm decreased slightly from day 0 to day 5 . There was no significant difference in live spermatozoa due to the extender after five day. The DNA was not unaltered by different of extender and storage refrigeration process. It concluded that kintamani dog semen qualities could be maintained for up five days when semen extended with coconut water-based extender with addition fructose and store at $4^{\circ} \mathrm{C}$.
\end{abstract}

Keywords | Kintamni dog, Chilled semen, Motility, Viability, DNA integrity

Editor | Kuldeep Dhama, Indian Veterinary Research Institute, Uttar Pradesh, India.

Received | February 17, 2018; Accepted | April 30, 2018; Published | May 17, 2018

*Correspondence | I Ketut Puja, Veterinary Genetics and Reproduction Technology Laboratory, Faculty of Veterinary Medicine, Udayana University, Bali Indonesia; Email: asubali@unud.ac.id

Citation | Puja IK, Sawitri NM, Maharani N, Gunawan IWNF, Heryani LGSS (2018). A comparative study on the effects of coconut water based extenders on the quality of kintamani dog semen preserved at $4^{\circ} \mathrm{C}$. Adv. Anim. Vet. Sci. 6(5): 192-196.

DOI | http://dx.doi.org/10.17582/journal.aavs/2018/6.5.192.196

ISSN (Online) | 2307-8316; ISSN (Print) | 2309-3331

Copyright (C) 2018 Puja et al. This is an open access article distributed under the Creative Commons Attribution License, which permits unrestricted use, distribution, and reproduction in any medium, provided the original work is properly cited.

\section{INTRODUCTION}

$\mathrm{T}$ he Kintamani dog is a favorite companion dog in Indonesia. The kintamani dog known as the gembrong dog has been bred in a village of Sukawana in the district of Kintamani in Bali for centuries. The Kintamani dog is emerging breed dog from Bali Indonesia. The characteristic temperament of the Kintamani dog is friendly and gentle dog make it a popular pet for the people in Indonesia, and efforts are being made to help it attain recognition by the Federation Cynologique Internationale (Puja et al., 2005). To produce a quality offspring, some breeders still use natural mating between dogs from remote locations. The natural mating often leads to stress dogs because they have to travel a long distance. (Hori et al., 2014). To solve these problems, we are interested in using artificial insemination techniques. As part of breeding management, the use of artificial (AI) is the way to offers excellent potential in accelerating the genetic improvement of kintamani dog.

AI can be performed using fresh chilled semen. Fresh Chilled semen was reported has similar pregnancy rates to fresh semen if applied soon after collection. To keep the survival of sperm after collection is needed a semen extenders. The appropriate extender for the preservation would be to minimize damage and to maintain the viability of spermatozoa. The extenders commonly used for chilled dog semen are based on animal products, such as e- 
Table 1: Composition of the extenders used in this study

\begin{tabular}{llllll} 
Ingredients & Extender A & Extender B & Extender C & Extender D & Extender E \\
Glucose & - & - & & 0,18 & $0,18 \mathrm{~g}$ \\
Fructose & - & $1,0 \mathrm{~g}$ & $1,0 \mathrm{~g}$ & & \\
Tris & $3,025 \mathrm{~g}$ & $2,4 \mathrm{~g}$ & $2,4 \mathrm{~g}$ & $3,025 \mathrm{~g}$ & 3,025 \\
\hline Egg-yolk & $20 \mathrm{ml}$ & - & - & - & - \\
Citric acid & $1,7 \mathrm{~g}$ & $1,3 \mathrm{~g}$ & $1,3 \mathrm{~g}$ & $1,7 \mathrm{~g}$ & 1,7 \\
Coconut water & - & - & $20 \mathrm{ml}$ & $20 \mathrm{ml}$ & \\
Pasteurized coconut water & & $20 \mathrm{ml}$ & & & $20 \mathrm{ml}$ \\
Penicilin & $0,65 \mathrm{mg} / \mathrm{ml}$ & $0,65 \mathrm{mg} / \mathrm{ml}$ & $0,65 \mathrm{mg} / \mathrm{ml}$ & $0,65 \mathrm{mg} / \mathrm{ml}$ & $0,65 \mathrm{mg} / \mathrm{ml}$ \\
\hline Streptomysin & $1 \mathrm{mg} / \mathrm{ml}$ & $1 \mathrm{mg} / \mathrm{ml}$ & $1 \mathrm{mg} / \mathrm{ml}$ & $1 \mathrm{mg} / \mathrm{ml}$ & $1 \mathrm{mg} / \mathrm{ml}$ \\
Ultra pure water & until $100 \mathrm{ml}$ & To 100 & To 100 & $25 \%$ & $25 \%$ \\
\hline pH & 6,6 & 6,6 & 6,6 & 6,6 & 6,6
\end{tabular}

gg yolk. Egg yolk the most common component used in canine semen extenders to protect spermatozoa from cold shock during chilled process (Mason, 2016). However, the presence of an avian influenza outbreak (Abe et al., 2008) and egg yolk affected by microbial contamination (Tarig et al., 2017) causes the desire to replace the egg yolk in extenders. Thus, it is necessary to develop extenders without use egg yolk. As an alternative to replace the egg yolk, coconut water to be especially suitable for chilled semen extender preparation in canine species since $\mathrm{pH}$ and ion compositions of coconut water similar to the plasma fluid. Coconut (Cocos nucifera) water also contains essential constituents such as sugar, vitamins, minerals, potassium, magnesium, fiber, and proteins (Silva and Bamunuarachchi, 2009) and has been reported to have antioxidant properties (Mantena et al., 2003).

Sugar is one of the main components in semen extenders. The most common sugar for canine semen extenders is fructose and glucose. Fructose and glucose addition to giving an energy substrate to spermatozoa and glucose and fructose are metabolized in separate pathways by freshly ejaculated dog sperm (Ponglowhapan et al., 2004). Spermatozoa metabolize both Glucose and fructose. However, fructose works better to preserve the viability of sperm.

In the interest of developing an efficient and natural extender, it is essential to study the effect of semen extenders containing unpasteurized coconut water, and pasteurized coconut water combined with different sugars on Motility, Viability, And DNA Integrity of Kintamani Dog Semen

\section{MATERIALS AND METHODS}

\section{Animal}

Four kintamani dogs between two and three years old, clinically healthy were used in this research. The dogs were kept in individual cages in $2 \times 4 \mathrm{~m}$ and fed twice daily with commercial dry food and give free access to water.

\section{Collection of Ejaculated Semen}

The ejaculates were obtained by manual stimulation into sterile tubes according to methods described by Puja (Puja, 2011). The first and third fractions of the ejaculate were discarded. Only the second fraction of the ejaculates was collected for the experiments.

\section{Evaluation of Fresh Semen}

The semen quality of was assessed immediately after collection. For the dogs to be included in the research before use is checked for motility. Only semen has $>80 \%$ motility used for this study. Semen is brought to the laboratory with a $4^{0} \mathrm{C}$ icebox. Sperm motility was evaluated using a light microscope $(100 \mathrm{x})$ according to the procedures of Johnston et al. (2001). The percentage of live spermatozoa were measured by eosin-nigrosin stain and evaluated microscopically (1000x) from 200 cells per slide. The DNA integrity assays for the quantification of DNA damage by AO test (Shamsi et al., 2011).

\section{Sperm Dilution}

All extenders were prepared in the laboratory using reagent chemicals purchased in Sigma. After evaluation, the sample was extended in unpasteurized coconut water $(\mathrm{CW})$ and pasteurized coconut water (PCW) based extender. Coconut water was pasteurized by boiling for 15 minutes at $65^{\circ} \mathrm{C}$. The coconut extender was combined with Two different of sugar. An extender containing Tris Egg yolk citric acid and no sugar supplementation served as a control. The composition of Five extenders was tested in this research reported in Table 1. Sperms were diluted in each of the five extenders at room temperature and then cooled to $4^{0} \mathrm{C}$ in a refrigerator. $100 \mu \mathrm{l}$ of each extender studied were placed in separate test tubes maintained at a room, then $200 \mu \mathrm{l}$ of semen was added to each of the tubes and then cooled to $4^{\circ} \mathrm{C}$ in a refrigerator. 
Table 2: Mean of motile spermatozoa in chilled canine semen from day 0 to day 5 in five extenders.

\begin{tabular}{lllllll} 
Extender & \multicolumn{2}{l}{ Motilities (\%) } & & & \\
& $\mathbf{0}$ day & $\mathbf{1}$ day & $\mathbf{2 ~ d a y s}$ & $\mathbf{3}$ days & $\mathbf{4}$ days & $\mathbf{5}$ days \\
A & $87,83 \pm 2,13$ & $85,00 \pm 2,68$ & $81,83 \pm 1,94$ & $74,06 \pm 1,78$ & $68,66 \pm 3,26$ & $65,10 \pm 2,40$ \\
B & $87,50 \pm 2,16$ & $84,66 \pm 2,16$ & $81,50 \pm 1,87$ & $73,50 \pm 1,37$ & $68,50 \pm 1,04$ & $62,83 \pm 0,75$ \\
C & $87,16 \pm 1,94$ & $83,00 \pm 1,78$ & $78,66 \pm 2,42$ & $67,50 \pm 1,37$ & $63,33 \pm 1,50$ & $57,83 \pm 1,16$ \\
D & $87,00 \pm 1,78$ & $84,16 \pm 1,94$ & $78,83 \pm 1,47$ & $64,33 \pm 1,63$ & $60,50 \pm 1,41$ & $54,16 \pm 1,47$ \\
E & $86,83 \pm 1,47$ & $84,00 \pm 1,78$ & $79,50 \pm 1,37$ & $63,66 \pm 0,81$ & $61,50 \pm 1,37$ & $57,00 \pm 2,09$ \\
\hline
\end{tabular}

Table 3: Percentage of live spermatozoa preserved at $+4^{\circ} \mathrm{C}$ in five the extender.

\begin{tabular}{|c|c|c|c|c|c|c|}
\hline \multirow[t]{2}{*}{ Extender } & \multicolumn{6}{|c|}{ LIVE spermatozoa (\%) } \\
\hline & 0 day & 1 day & 2 days & 3 days & 4 days & 5 days \\
\hline A & $92,16 \pm 2,75$ & $90,50 \pm 3,08$ & $88,66 \pm 3,61$ & $87,16 \pm 3,60$ & $85,50 \pm 4,03$ & $84,16 \pm 3,76$ \\
\hline B & $91,83 \pm 2,63$ & $90,83 \pm 2,31$ & $89,16 \pm 3,31$ & $87,00 \pm 3,34$ & $85,16 \pm 4,07$ & $83,5 \pm 3,93$ \\
\hline $\mathrm{C}$ & $92,00 \pm 2,75$ & $90,00 \pm 2,96$ & $87,66 \pm 3,55$ & $86,00 \pm 2,75$ & $84,00 \pm 3,34$ & $82,16 \pm 4,52$ \\
\hline $\mathrm{D}$ & $92,16 \pm 2,99$ & $89,83 \pm 2,78$ & $87,83 \pm 3,12$ & $86,16 \pm 3,06$ & $84,16 \pm 3,60$ & $82,33 \pm 3,38$ \\
\hline $\mathrm{E}$ & $92,16 \pm 2,99$ & $90,50 \pm 2,33$ & $88,16 \pm 2,78$ & $86,16 \pm 3,06$ & $84,83 \pm 3,12$ & $83,33 \pm 3,14$ \\
\hline
\end{tabular}

Table 4: Percentage of DNA integrity preserved at $+4^{\circ} \mathrm{C}$ in five extender.

\begin{tabular}{|c|c|c|c|c|c|c|}
\hline \multirow[t]{2}{*}{ Extender } & \multicolumn{6}{|c|}{ DNA Integrity (\%) } \\
\hline & 0 day & 1 day & 2 days & 3 days & 4 days & 5 days \\
\hline A & $96.83 \pm 1.16$ & $96,83 \pm 1.16$ & $96.66 \pm 1.21$ & $96.50 \pm 1.04$ & $96.00 \pm 0.89$ & $95.00 \pm 1.22$ \\
\hline B & $97.16 \pm 0.98$ & $96.50 \pm 1.22$ & $96.33 \pm 1.36$ & $96.14 \pm 1.16$ & $96.00 \pm 1.26$ & $95.83 \pm 1.17$ \\
\hline $\mathrm{C}$ & $97.16 \pm 0.75$ & $96.66 \pm 0.81$ & $95.83 \pm 1.16$ & $95.83 \pm 1.16$ & $95.66 \pm 1.21$ & $95.50 \pm 1.22$ \\
\hline $\mathrm{D}$ & $97.16 \pm 0.75$ & $96.66 \pm 0.81$ & $96.16 \pm 0.98$ & $95.83 \pm 1.16$ & $95.83 \pm 1.16$ & $95.66 \pm 1.12$ \\
\hline $\mathrm{E}$ & $97.00 \pm 0.63$ & $96.33 \pm 1.03$ & $96.16 \pm 0.98$ & $95.83 \pm 0.75$ & $95.83 \pm 0.75$ & $95.50 \pm 0.83$ \\
\hline
\end{tabular}

\section{Statistical Analysis}

The effect of extenders on motility, viability and DNA integrity were performed by ANOVA (Heath, 2000). Data gathered in this experiment were statistically analyzed using SPSS version 23.0.

\section{RESULT}

\section{Evaluation of Fresh Ejaculate Semen}

In fresh ejaculate semen, the average volume of the second (sperm-rich) fraction in a kintamni dog was $1.2 \pm 0.18 \mathrm{ml}$ with a sperm concentration of $643.33 \times 10^{6 /} / \mathrm{ml}$. The average percentage of life was $93.25 \%$, and the DNA integrity was 98.00 . Spermatozoa motility was 91.00 .

\section{Evaluation of Sperm Motility after Chilled}

In this research, the percentage of motility, live and DNA integrity were compared in five different extenders on the day of the sampling and daily until the five days after sampling. Mean Sperm motility after treatment is shown in Table 2. The progressive motility of the sperm cells was significantly higher than the in extender A and B compared to other extenders $(p<0.01)$. Semen quality based on motility after five days seen the same result in extender A and $\mathrm{B}(\mathrm{p}>0.05)$. The extender containing $20 \%$ egg yolk and $20 \%$ pasteurized coconut water and an addition of $1.0 \mathrm{~g}$ fructose preserved the motility of more than $60 \%$ of the spermatozoa up to the 5 - day post-sampling. The type of coconut water and sugar affected motility. The percentage of motility decreased significantly from day 1 until day 5 in all treatments.

\section{Evaluation of Live Sperm after Chilled}

The mean lives sperm percentage in five different extenders on the day of the sampling and daily until the five day after sampling recorded was above $80 \%$ with the range from 82,16 to $84,16 \%$. Mean of live Sperm after treatment is shown in Table 3. Percentage of live sperm decreased slightly from day 0 to day 5 . However, The mean of live sperm in did not decrease significantly from Day 0 to Day $1((p<0,01)$. In the analysis of the percentage of live sperm showed that the semen samples in five different did not differ $(\mathrm{P}>0.05)$.

\section{Assesment of DNA Integrity of Sperm AFter Chilled \\ This is used to assess damage to the cellular DNA. Sperm DNA integrity after treatment could be seen in Table 4.}


The DNA integrity was unaltered by the chilled process. The percentages of sperm with DNA integrity did not differ $(\mathrm{P}>0.05)$ among the extender. The result of five different extenders was preserved the DNA integrity of more than $95 \%$ However the DNA integrity decreased slightly with the storage time.

\section{DISCUSSION}

The characteristics of the fresh semen it is shown that the total number of spermatozoa, the percentage of motility and DNA integrity were within the physiologic range for dogs (Johnston et al., 2001).

In this study, the extenders used in this study were provided an adequate medium to sustain the kintamani dog sperm quality. The pasteurized coconut water extenders addition with fructose were efficient conserving up to the 5 -day post-sampling. The mean motility of sperm in pasteurized coconut water was significantly different than unpasteurized. The obtained results indicate that that pasteurized the biochemical characteristic unchanged during boiled and eradicate the microbiological load (Adubofuor et al., 2016) This extender has preserved the motility of more than $60 \%$. In this result demonstrated that coconut water-based extender with addition fructose seen to the ability to maintain the sperm motility, viability and DNA integrity same than the egg yolk citrate extenders (control).

It was observed that chilling was the most suitable method of semen storage and chilling still survive approximately 4-5 days of collection (England and Ponzio, 1996). This result indicated that coconut water-based extenders good effect for the preservation of kintamani dog semen for a short-time (5 days). The survival of sperm observed in the present study could be linked to essential constituents such as sugar, minerals and amino acids, and ion in coconut water (Vigliar et al., 2006) and antioxidant activities (Silva and Bamunuarachchi, 2009).

The supplementation of different type of sugar in coconut water-based extender improves quality of motility. In a recent study, coconut water-based extender with addition fructose has same effectiveness in preserving the motility sperm at $4^{\circ} \mathrm{C}$ as an egg-yolk citrate extender. The type of sugar significantly affected motility during storage (Yildiz et al., 2000). The role of fructose as in extenders is known to increase the osmotic potential of cells and protect the membrane from chilling-induced injury and fructose in coconut water extender could be used by spermatozoa for energy resources. (Ponglowhapan et al., 2004).

Analysis percentage of live spermatozoa showed no significant differences between extenders and control extender. The mean of live sperm is higher than the mean of motile spermatozoa (Bearden and Fuquay, 1997) because the sperm that lives is not necessarily motile, but some spermatozoa are not motile sometimes still alive (Campbell et al., 2003). The presence of antioxidants, sugar, vitamins, electrolytes and amino acids and essential inorganic compounds in the coconut extenders (Yong et al., 2009) then the effects of cold shock can be minimized so that the spermatozoa deaths can be prevented. The Extender used in this study is considered to be an important buffer and nontoxic that determine the success of sperm storage (Cardoso et al., 2005).

Besides motility and viability of spermatozoa, the DNA integrity is required to the assessment of the quality of spermatozoa (Kim et al., 2010). DNA integrity as one of the parameters determining male fertility (Tejada et al., 1984; Agarwal and Said, 2003; Chohan et al., 2006). Tests for DNA integrity are most promising to asses the sperm reproductive potential (Shamsi et al., 2011). The Acridine Orange (AO) test is used to assess the DNA integrity. This staining technique differentiates between cells with intact DNA; AO fluoresced green whereas AO associated with denatured DNA fluoresced orange or red (Hasegan et al., 2012). The DNA was not unaltered by different of extender and storage refrigeration process. This conclusion is supported by the study of Prinosilova et al. (2011) who suggested that chilled and cryopreservation did not cause any significant changes in DNA integrity. According to the presented results during refrigeration, very little denaturation is seen (Bencharif et al., 2013). Different results were found by Urbano et al. (2017) evaluating the DNA integrity in cooled dog sperm using the SCD. It seems that the extenders and storage temperature of $4{ }^{\circ} \mathrm{C}$ can protect sperm DNA integrity of semen.

\section{CONCLUSION}

The addition of fructose in coconut water-based extender able to maintain motility, viability, and spermatozoa DNA integrity of kintamani dog during refrigeration process. This result indicated that coconut water-based extenders good effect for the preservation of kintamani dog semen for a short-time (5 days).

\section{ACKNOWLEDGEMENTS}

The authors thanks to the Udayana University for finacial support by Invention grant research 2017. We also thanks to.Komang Yogi Suryana, DVM and Yoga Windu,DVM for technical assistance to prepare the sample

\section{CONFLICT OF INTERESTS}

The authors declare that they have no conflict of interests. 


\section{AUTHORS CONTRIBUTION}

All of the authors have read and approved the manuscript.

\section{REFERENCES}

-Abe Y, Lee DS, Sano H (2008). Artificial insemination with canine spermatozoa frozen in a skim milk/glucosebased extender. J. Reprod. Dev. 54:290-294. https://doi. org/10.1262/jrd.19148

-Adubofuor J, Amoah I, Osei-Bonsu I (2016). Sensory and Physicochemical Properties of Pasteurized Coconut Water from Two Varieties of Coconut. Food Sci. Qual. Manag. 54: 26-32.

- Agarwal, Said A (2003). Role of sperm chromatin abnormalities and DNA damage in male infertility. Hum. Reprod. Update. 9: 331-345. https://doi.org/10.1093/humupd/dmg027

- Bearden HJ, Fuquay (1997). The Male Reproduction System. In: Applied Animals Reproduction 4th (Ed). New Jersey: Prentice.

-Bencharif D, Amirat-Briand L, Le Guillou J. Vitelli C, Anton M, Schmitt E, Desherces S, Barriere P, Tainturier D (2013). Refrigeration of canine sperm at $+4^{\circ} \mathrm{C}$ : Comparative study of four different extenders for the refrigeration of canine sperm at $+4^{\circ} \mathrm{C}$ : LDL, Tris egg yolk, Equex ${ }^{\circledR}$, and INRA96 ${ }^{\circledR}$. Rev. Med. Vet. 164 (5): 252-262.

-Campbell J R, Campbell KL, Kenealy MD (2003). Artificial insemination. In: Anim. Sci. 4 the (Ed). Mc Graw-Hili. New York.

- Cardoso RCS, Silva AR,Silva LDM (2005). Use of the powdered coconut water (ACP-106 $\left.{ }^{\circledR}\right)$ for cryopreservation of canine spermatozoa. Anim. Reprod. 2 (4): 257-262

- Chohan KR, Griffin JT, Lafromboise M, De Jonge CJ,Carrell DT (2006). Comparison of chromatin assays for DNA fragmentation evaluation in human sperm. J. Androl. 27: 53-59. https://doi.org/10.2164/jandrol.05068

- England GCW, Ponzio P (1996). Comparison of the quality of frozen-thawed and cooled-rewarmed dog semen. Theriogenology. 46 (1): 165-171. https://doi. org/10.1016/0093-691X(96)00151-3

-Hasegan I, Sonea A, Matei M, Vintila L, Camelia I, Birtoiu A (2012). Semen Collection, Assessment, and Processing for in vitro Fertilization in Dog - a Review. Anim. Sci. Biotechnol. 45 (1): 163-171.

-Heath D (2000). An Introduction to Experimental Design and Statistics for Biology.UCL Press. London.

-Hori T, Yoshikuni R, Kobayashi M, Kawakami E (2014). Effects of storage temperature and semen extender on stored canine semen. J. Vet. Med. Sci. 76(2): 259-263. https://doi. org/10.1292/jvms.13-0303

-Johnston SD (1991). Performing a complete canine semen evaluation in the small animal hospital. Vet. Clin. North Am. Small Anim. Pract. 21: 545-551. https://doi.org/10.1016/ S0195-5616(91)50060-7

-Johnston S, Kustritz MR, Olson P (2001). Semen collection, evaluation and preservation. In: Johnston S, Kustritz MR, Olson P (eds), Canine and Feline Theriogenology. WB Saunders, New York, Pp. 287-307.

-Kim SH, Yu DH, Kim YJ (2010). Effects of cryopreservation on phosphatidylserine translocation, intracellular hydrogen peroxide, and DNA integrity in canine sperm. Theriogenology. 73: 282-292. https://doi.org/10.1016/j. theriogenology.2009.09.011

- Mantena SK,Jagadish,Badduri SR, Siripurapu KB,Unnikrishnan MK (2003). In vitro evaluation of antioxidant properties of Cocos nucifera Linn. water. Nahrung. 47(2):126-31. https:// doi.org/10.1002/food.200390023

- Mason S (2016). Canine chilled and frozen semen preparation and artificial insemination. Proceedings of the Australian Reproduction Veterinarians 2016 Seminar: Canine Reprod. Micro.

- Ponglowhapan S, Essen-Gustavsson B, Linde-Forsberg C (2004). Influence of glucose and fructose in the extender during long-term storage of chilled canine semen. Theriogenology. 62: 1498-1517. https://doi.org/10.1016/j. theriogenology.2004.02.014

- Prinosilova P, Rybar R, Zajicova A, Hlavicova J (2012). DNA integrity in fresh, chilled and frozen-thawed canine spermatozoa. Vet. Med. 57 (3): 133-142. https://doi. org/10.17221/5853-VETMED

-Puja IK, Irion DN, Schaffer AL, Pedersen NC (2005). The Kintamani dog: genetic profile of an emerging breed from Bali, Indonesia.J. Hered. 96(7): 854-859.

-Puja IK (2011). Aspek Reproduksi Pada Pengembangan Anjing.2ed. Udayana University Press.

- Shamsi MB, Imam SN, Dada R (2011). Sperm DNA integrity assays: diagnostic and prognostic challenges and implications in the management of infertility. J. Assist. Reprod. Genet. 28(11): 1073-1085. https://doi.org/10.1007/s10815-0119631-8

- Silva PSA, Bamunuarachchi A (2009). Manufacture of carbonated tender coconut water and development of a process for the utilization of coconut flesh. As. J. Food AgInd. 2: 210-213

- Tarig AA, Wahid H, Rosnina Y, Yimer N, Goh YM, Baiee FH, Khumran AM, Salman H, Assi MA, Ebrahimi M (2017). Effect of different concentrations of soybean lecithin and virgin coconut oil in Tris-based extender on the quality of chilled and frozen-thawed bull semen. Vet. World. 10(6): 672-678. https://doi.org/10.14202/vetworld.2017.672-678

- Tejada RI, Mitchell JC, Norman A, Marik JJ, Friedman SA (2016). A.Test for the practical evaluation of male fertility by acridine orange (AO) fluorescence. Fertil. Steril. 42:8791.

-Urbano M, Ortiz I, Dorado J, Hidalgo M (2017). Identification of sperm morphometric subpopulations in cooled-stored canine sperm and its relation to sperm DNA integrity. Reprod. Dom. Anim. 52: 468-476. https://doi.org/10.1111/ rda.12935

- Vigliar R, Vera L, Sdepanian, Fagundes-Neto U (1996). Biochemical profile of coconut water from coconut palms planted in an inland region. J. Pediatr. (Rio J). 82(4): 308-12:

-Yildiz C, Kaya A, Aksoy M, Tekeli T (2000). Influence of Sugar Supplementation of the Extender on Motility, Viability, and Acrosomal Integrity of Dog Spermatozoa During Freezing. Theriogenology. 54: 579-585.

-Yong JWH, Ge L, Ng YF, Tan SN (2009). The chemical composition and biological properties of coconut (Cocos nucifera L.) water. Molecules. 14: 5144-5164. https://doi. org/10.3390/molecules14125144 